the Society should write to: The Kenya Museum Society, Kenya National Museums, P.O. Box 40658 , Nairobi, Kenya.

\title{
Atlas pratique du Tchad
}

Publí par l'Institut National Tchadien pour les Sciences Humaines et par l'Institut Géographique National, l'Atlas du Tchad a été élaboré sous la direction de Jean Cabot et de Christian Bouquet. Il comporte un avant-propos de Jean-Paul Lebeuf et une préface de Jean Dresch.

Trente quatre planches présentent les données les plus récentes sur la géographie physique, humaine et économique de la République du Tchad. Après avoir présenté le Tchad dans le monde et en Afrique on découvre l'organisation administrative du pays et ses voies de communication. Une série de cartes physiques présentent l'orohydrographie, la géologie, la pédologie et l'hydrogéologie de la partie tchadienne de la grande cuvette d'Afrique Centrale.

Trois planches très expressives expliquent le fonctionnement du climat, ses variations saisonnières et ses principales caractéristiques. Une carte de la végétation complète ce tour d'horizon physique.

La partie humaine débute avec la carte de l'archéologie (paléontologie, préhistoire, proto-histoire) dont les vestiges sont nombreux au Tchad. Une carte très détaillée des groupes linguistiques contribuera à une meilleure connaissance des parlers tchadiens. La répartition de la population en I 968 fait également l'objet d'une carte.

Quatre planches à grande échelle présentent les terroirs types de l'agriculture tchadienne : cultures sèches, cultures de bas-fond, polders etc. . . .

Les cartes économiques concernent les productions agricoles, la pêche, la culture du coton, l'élevage, les activités industrielles, le commerce extérieur.

La dernière partie est consacrée aux plans de villes (Fort-Lany, Fort-Archambault, Moundou, Abéché) et aux équipements sociaux et culturels ainsi qu'au tourisme. Trois cartes à moyenne échelle présentent trois régions de la république : la région du lac, celle du Ouaodai et la région cotonnière.

Conçu pour être mis entre les mains des cadres du pays cet ouvrage rendra les plus grands services aux chercheurs désireux de se documenter sur le Tchad.

\section{'Odinani Museum and Journal', Nri, East Central State, Nigeria}

As a joint project of the Nri Progress Union and the Institute of African Studies, University of Ibadan, a museum has been established at Nri. It was opened in March 1972 and has as its objective the collection, display, and study of the material cultures of the peoples of the East Central State. It plans to publish twice a year issues of the Journal of Odinani Museum, $\mathrm{Nri}$, of which the first issue appeared in March 1972.

The honorary curator of the museum and editor of the journal is Mr. Onwuejeogwu, Research Fellow in Anthropology of the Institute of African Studies, Ibadan, who has been engaged since I 966 on a special study of the extant cultures of the Igbo in the general area of Igbo-Ukwu site where Professor Thurstan Shaw conducted the excavations which yielded the remarkable ritual assemblages of bronze and pottery objects associated with an elaborate ceremonial burial (Shaw, T. Igbo-Ukwu: an account of archacological discoveries in Eastern Nigeria, 2 vols., Faber \& Faber, London, 1970).

The first issue of the journal records the co-operation and contributions given to establish the museum, together with a main article by the editor, "An outline of the dawn of Igbo civilisation', which offers a reconstruction, with reference to the ecological background, external relations, and the role of the sacred kingship at Nri, of the development and diversity of social institutions among the Igbo. 